\title{
Epiphloea belongs to Collemataceae (Lecanoromycetes, lichenized Ascomycota)
}

\author{
Matthias SCHULTZ, Mats WEDIN, Henrike DIEL and Maria PRIETO
}

\begin{abstract}
The cyanolichen genus Epiphloea is currently included within the Heppiaceae (Lichinomycetes) based on ascus characteristics. The presumed presence of a prototunicate ascus has been used as support for this classification, despite the incongruence with other characters (e.g. spores). Here, we use a molecular phylogeny of the two markers mtSSU rDNA and $M c m 7$ to investigate the position of Epiphloea. In addition, we have re-investigated the ascus characteristics. Our results place the two species, Epiphloea byssina and E. terrena, within the Collemataceae, nested in Leptogium s. str. The ascus type in both species is shown to be Lecanoralean and similar to the ascus in other Collemataceae, with a strongly amyloid tube-like structure. This observation supports the placement within Lecanoromycetes and refutes the earlier suggested affinities with Heppiaceae and Lichinomycetes. The correct names for these species are Leptogium byssinum and Leptogium terrenum.
\end{abstract}

Key words: cyanolichens, Leptogium, lichens, Lichinomycetes, phylogeny, systematics, taxonomy

Accepted for publication 13 August 2015

\section{Introduction}

Current progress in our understanding of the relationships among Ascomycota is substantial, and the recent advances in the phylogeny and evolution of lichen-forming Ascomycota associating with cyanobacteria is no exception (Schoch et al. 2009; Wedin et al. 2009, 2011; Otálora \& Wedin 2013; Otálora et al. 2013, 2014; Spribille \& Muggia 2013; Ekman et al. 2014; Magain \& Sérusiaux 2014; Miądlikowska et al. 2014). Identifying and interpreting characters relevant for the classification of higher taxonomic ranks is a fundamental question in the phylogeneticsystematic study of the Ascomycota. Fungal classification is full of examples of groups where the current taxonomy is based on erroneous or dubious observations or

M. Schultz: Herbarium Hamburgense, Biocenter Klein Flottbek, University of Hamburg, Ohnhorststraße 18, D-22609 Hamburg, Germany. Email: matthias.schultz@ uni-hamburg.de

M. Wedin and M. Prieto: Swedish Museum of Natural History, Department of Botany, P.O. Box 50007, SE-10405 Stockholm, Sweden.

H. Diel: University Medical Center HamburgEppendorf, Campus Forschung (N27), Martinistraße 52, D-20246 Hamburg, Germany. interpretations of morphological structures. This is a problem which is particularly relevant for small and inconspicuous groups of cyanobacterial lichens.

During our ongoing studies of the phylogeny and character evolution of the Lichinomycetes, one of the largest remaining poorly understood groups of cyanobacterial lichens, a highly deviant genus was found to be Epiphloea, where the sequences of all molecular markers obtained were very different from other Lichinomycetes. Preliminary BLAST searches showed similarities with the Collemataceae, another group of cyanobacterial lichens. Epiphloea has for a long time been considered closely related to the Lichinomycete genus Heppia in Heppiaceae (Zahlbruckner 19241925; Eriksson 1999; Lumbsch \& Huhndorf 2007), although they differ in spore characteristics and photobiont (i.e. Nostoc and muriform spores in Epiphloea, Scytonema and simple spores in Heppia). In the latest major treatment of Epiphloea, Jørgensen (2007) reported the asci to be prototunicate (thin-walled throughout and opening by apical rupturing), a common trait in Lichinomycetes. Jørgensen's statement, however, differs from earlier observations by Zahlbruckner (1919), who 
described the asci as having rounded and, at first, thickened tips that suggests a nonprototunicate ascus type.

The aim of this study is to clarify the phylogenetic placement of Epiphloea. To achieve this, we performed a phylogenetic analysis which included putative relatives based on DNA sequences of the mitochondrial SSU rDNA and the nuclear protein coding gene $M c m 7$. In order to re-evaluate and assess relevant morphological attributes, we studied the thallus and ascoma characteristics of both species in the genus, including type material, with particular focus on the ascus apex characteristics.

\section{Material and Methods}

\section{Molecular study}

For the phylogenetic study, we included three samples of Epiphloea and a wide selection of Collemataceae members (Table 1), representing all groups identified by Otálora et al. $(2013,2014)$. As in these previous studies, we used two members of Pannariaceae, Pannaria rubiginosa (Thunb. ex Ach.) Delise and Staurolemma omphalarioides (Anzi) P. M. Jørg. \& Henssen, as outgroups rooting the tree with the latter. DNA was extracted using DNeasy Plant Mini Kit (Qiagen) and innuPREP Plant DNA Kit (Analytik Jena), according to the manufacturers' instructions. Amplifications were performed using 1:10 diluted DNA and with mtSSU1 and mtSSU3R (Zoller et al. 1999) primers for the $\mathrm{mtSSU}$ region. For amplification of the $\mathrm{Mcm} 7$ region, we used the primers Mcm7-709for and Mcm7-1348rev (Schmitt et al. 2009). When no bands were obtained in the PCR, we carried out a nested PCR using $1 \mu$ of the PCR product and the internal primers $M c m 7-C a l i c F$ and Mcm7-CalicR (Prieto et al. 2013).

PCR amplifications were performed using Illustra ${ }^{\mathrm{TM}}$ Hot Start Mix RTG PCR beads (GE Healthcare, UK) in a $25 \mu \mathrm{l}$ volume, containing $3 \mu \mathrm{l}$ of diluted genomic DNA, $10 \mu \mathrm{M}$ of each primer and distilled water. Amplifications were performed using the following procedure: initial denaturation at $95^{\circ} \mathrm{C}$ for $15 \mathrm{~min}$, followed by 35 cycles of $95^{\circ} \mathrm{C}$ for $45 \mathrm{~s}, 56^{\circ} \mathrm{C}$ for $50 \mathrm{~s}, 72^{\circ} \mathrm{C}$ for $1 \mathrm{~min}$, followed by a final extension at $72^{\circ} \mathrm{C}$ for $5 \mathrm{~min}$. PCR products were subsequently purified using the enzymatic method Exo-sap-IT (USB Corporation, Santa Clara, California, USA) or spin columns (Geneaid Gel/PCR DNAFragments Extraction Kit). The purified PCR products were sequenced using the same amplification primers.

Sequences were assembled and edited using Sequencher v. 4.10.1. (Genes Codes Corporation, Ann Arbor) and deposited in GenBank (Table 1). These sequences were added to the Collemataceae alignment provided by Otálora et al. (2013), using MacClade 4.01
(Maddison \& Maddison 2001) and adjusted and reduced manually. Ambiguous regions (sensu Lutzoni et al. 2000) and introns were delimited manually and excluded from the phylogenetic analyses.

Independent analyses were carried out in both data sets (i.e. mtSSU and $M c m 7$ alignments) using maximum likelihood-based inference (ML) in RAxML ver. 8.1.11 (Stamatakis 2014) and a GTRGAMMA model for tree inference. Bootstrapping was performed with a GTRCAT model and 1000 replicates. In order to check incongruence between the two analyses, we compared ML-BS individual gene trees, considering a conflict when a supported clade (bootstrap support $>70 \%$ ) for one marker was contradicted with significant support by another. Because no supported nodes were in conflict, the data were combined into a single data matrix. The combined maximum likelihood (ML) analyses were run with three distinct partitions (mtSSU, 1st and 2nd codon position for $M c m 7$ and the 3rd codon position for $M c m 7$ ), using the same settings as in the individual analysis.

We selected the best-fit models of nucleotide substitutions based on the Akaike Information Criterion (AIC) using jModeltest 0.1.1 (Posada 2008). The GTR model (Rodríguez et al. 1990) was selected for the three partitions, with a gamma distributed rate variation across sites with four categories and an estimated proportion of invariable sites. All parameters were unlinked, with rates allowed to vary across partitions under a flat Dirichlet prior.

The Bayesian inference was performed using MrBayes 3.2.3 (Ronquist et al. 2012). Two runs of 10 million generations, starting from an initial random tree and employing four simultaneous chains, were executed. A tree was saved every 100th generation. To ensure that stationarity and convergence were reached, to verify if mixing was appropriate, and choose a suitable burn-in, we plotted the log-likelihood values against the time generation with Tracer v.1.5.0 (Rambaut \& Drummond 2007). A burn-in sample of 25000 trees was discarded for each run. The remaining 150000 trees (pooled from both independent runs) were used to estimate branch lengths and posterior probabilities (PPs). The analyses were run on the CIPRES Science Gateway v. 3.3 (Miller et al. 2010).

Selected specimens examined. Epiphloea byssina (Hoffm.) Henssen \& P. M. Jørg. Germany: Baden-Württemberg: Heidelberg, $W$. v. Zwackh-Holzhausen (Lich. exs. 174) (UPS 111320 (L-62566)—neotype!; M-0154536, M-0154537-isoneotypes!). Bavaria: ad terram nudam prope Eichstadt [Eichstätt] in Bavaria, F. Arnold (Körber, Lich. Sel. Germ. 60; as Collema cheileum var. byssinum) (B).-Poland: Wojew. Dolnoślaskie: Silesia, Hirschberg, auf Mauern, f. v. Flotow (Deutsch. Lich. 143A; as Collema cheileum var. byssaceum) (HBG).Sweden: Uppland: Bondkyrko par., Norby, auf lehmigen Äckern, 7 vii 1920, G. Du Rietz (as f. obscurius Du Rietz) (B).-Norway: Oppland: Vågå municip., Nordherad, E of Svarthåmårbekken, by the parking lot just $S$ of the road $\mathrm{Fv}_{4} 454$, on soil, $61.8674^{\circ} \mathrm{N}, 8.9886^{\circ} \mathrm{E}$, 680 m, 30 vi 2013, M. Westberg (S F264803).-Russia: Sverdlovsk: Distr. Pervouralsk, Sloboda village, limestone outcrops on Chusovaya River, on soil, 2002, A. Paukov AGP20020804-02 (UFU) (dupl. hb. Schultz). 
TABLE 1. GenBank accession numbers for specimens used in this study. New sequences are indicated by accession numbers in bold.

\begin{tabular}{|c|c|c|c|}
\hline \multirow[b]{2}{*}{ Species } & \multirow[b]{2}{*}{ Voucher specimen } & \multicolumn{2}{|c|}{ GenBank Acc. number } \\
\hline & & mtSSU & Mcm 7 \\
\hline Blennothallia crispa (Huds.) Otálora et al. 1 & & JX992918 & JX992976 \\
\hline B. crispa (Huds.) Otálora et al. 2 & & JX992919 & JX992977 \\
\hline B. crispa (Huds.) Otálora et al. 3 & & JX992920 & JX992978 \\
\hline Collema furfuraceum (Arnold) Du Rietz & & EU982567 & JX992982 \\
\hline C. leptaleum Tuck. 1 & & JX992928 & JX992986 \\
\hline C. leptaleum Tuck. 2 & & JX992929 & JX992987 \\
\hline C. nigrescens (Huds.) DC. & & EU982563 & JX992989 \\
\hline C. rugosum Kremp. & & JX992936 & JX992995 \\
\hline C. subconveniens Nyl. 1 & & JX992937 & JX992996 \\
\hline C. subconveniens Nyl. 2 & & JX992938 & JX992997 \\
\hline Enchylium bachmanianum (Fink) Otálora et al. & & JX992914 & JX992974 \\
\hline E. polycarpon (Hoffm.) Otálora et al. 1 & & JX992935 & JX992994 \\
\hline E. polycarpon (Hoffm.) Otálora et al. 2 & & JX992935 & JX992994 \\
\hline E. tenax (Sw.) Gray & & EU982556 & JX992998 \\
\hline Lathagrium auriforme (With.) Otálora et al. & & EU982568 & - \\
\hline L. cristatum (L.) Otálora et al. & & DQ917409 & JX992979 \\
\hline L. fuscovirens (With.) Otálora et al. & & JX992923 & JX992983 \\
\hline L. undulatum (Flot.) Otálora et al. & & EU982554 & JX993000 \\
\hline Leptogium azureum (Sw.) Mont. & & JX992939 & JX993002 \\
\hline L. biloculare F. Wilson & & JX992942 & JX993004 \\
\hline L. brebissonii Mont. & & EU982583 & JX993005 \\
\hline L. britannicum P. M. Jørg. \& P. James & & JX992944 & JX993037 \\
\hline L. byssinum (Hoffm.) Zwackh ex Nyl. & $\begin{array}{l}\text { Norway, Westberg } \\
\text { (S F264803) }\end{array}$ & KT240180 & KT240183 \\
\hline L. corticola (Taylor) Tuck. & & EU982585 & JX993008 \\
\hline L. crispatellum Nyl. & & JX992945 & JX993009 \\
\hline L. cyanescens (Rabenh.) Körb. & & EU982561 & JX993010 \\
\hline L. dactylinum Tuck. & & JX992946 & JX993011 \\
\hline L. denticulatum Nyl. 1 & & JX992947 & JX993012 \\
\hline L. denticulatum Nyl. 2 & & JX992948 & JX993013 \\
\hline L. digitatum (A. Massal.) Zahlbr. & & JX992950 & JX993016 \\
\hline L. furfuraceum (Harm.) Sierk & & EU982553 & JX993017 \\
\hline L. isidiosellum (Riddle) Sierk & & JX992953 & JX993018 \\
\hline L. juressianum Tav. & & JX992954 & JX993019 \\
\hline L. laceroides B. de Lesd. & & JX992955 & JX993020 \\
\hline L. malmei P. M. Jørg. & & JX992956 & JX993023 \\
\hline L. marginellum (Sw.) Gray & & JX992957 & JX993024 \\
\hline L. papillosum (B. de Lesd.) C. W. Dodge & & JX992961 & JX993027 \\
\hline L. phyllocarpum (Pers.) Mont. 1 & & EU982589 & JX993028 \\
\hline L. phyllocarpum (Pers.) Mont. 2 & & EU982588 & JX993029 \\
\hline L. pseudofurfuraceum P. M. Jørg. \& A. K. Wallace & & EU982562 & JX993031 \\
\hline L. resupinans $\mathrm{Nyl}$. & & JX992963 & JX993033 \\
\hline L. reticulatum Mont. & & JX992964 & JX993038 \\
\hline L. rivulare (Ach.) Mont. 1 & & JX992965 & - \\
\hline L. rivulare (Ach.) Mont. 2 & & JX992966 & - \\
\hline L. saturninum (Dicks.) Nyl. 1 & & EU982569 & JX993034 \\
\hline L. saturninum (Dicks.) Nyl. 2 & & AY340499 & JX993035 \\
\hline L. sessile Vain. & & JX992967 & JX993007 \\
\hline L. terrenum Nyl. 1 & $\begin{array}{l}\text { Portugal, van den Boom } 41781 \\
\text { (hb. van den Boom) }\end{array}$ & KT240181 & KT240184 \\
\hline L. terrenum Nyl. 2 & $\begin{array}{l}\text { Portugal, Amieiro, } \\
\text { Marques (PO) }\end{array}$ & KT240182 & KT240185 \\
\hline L. velutinum P.M. Jørg. & & JX992972 & JX993041 \\
\hline Pannaria rubiginosa (Thunb.) Delise & & AY360513 & JX993042 \\
\hline Paracollema italicum (B. de Lesd.) Otálora et al. 1 & & JX992925 & JX992984 \\
\hline
\end{tabular}


TABle 1. Continued

\begin{tabular}{|c|c|c|c|}
\hline \multirow[b]{2}{*}{ Species } & \multirow[b]{2}{*}{ Voucher specimen } & \multicolumn{2}{|c|}{ GenBank Acc. number } \\
\hline & & mtSSU & Mcm 7 \\
\hline P. italicum (B. de Lesd.) Otálora et al. 2 & & JX992926 & JX992985 \\
\hline Pseudoleptogium diffractum (Körb.) Müll. Arg. & & JX992949 & JX993015 \\
\hline Rostania multipunctata (Degel.) Otálora et al. & & JX992930 & JX992988 \\
\hline R. occultata (Bagl.) Otálora et al. & & JX992931 & JX992990 \\
\hline Scytinium biatorinum (Nyl.) Otálora et al. & & JX992940 & JX993003 \\
\hline S. fragrans $(\mathrm{Sm}$.$) Otálora et al.$ & & JX992922 & JX992981 \\
\hline S. lichenoides (L.) Otálora et al. & & DQ923120 & JX993021 \\
\hline S. magnussonii (Degel. \& P. M. Jørg.) Otálora et al. & & EU982565 & JX993022 \\
\hline S. palmatum (Huds.) Gray 1 & & JX992959 & JX993025 \\
\hline S. palmatum (Huds.) Gray 2 & & JX992960 & JX993026 \\
\hline S. parvum (Degel.) Otálora et al. & & JX992933 & JX992992 \\
\hline S. plicatile (Ach.) Otálora et al. & & GQ259033 & JX993030 \\
\hline S. pulvinatum (Hoffm.) Otálora et al. & & EU982590 & JX993032 \\
\hline S. schraderi (Bernh.) Otálora et al. & & EU982559 & JX993036 \\
\hline S. turgidum (Ach.) Otálora et al. & & EU982592 & JX993040 \\
\hline Staurolemma omphalarioides (Anzi) P. M. Jørg. \& Henssen & & EU982560 & JX993043 \\
\hline
\end{tabular}

Epiphloea terrena (Nyl.) Trevis. France: LanguedocRoussillon, Dept. Pyrénées Orientales: Colliour, Pla de las Fourques, in fossa arcis Fortrand, 5 vii 1872, W. Nylander (H-NYL 42806-lectotype!). ProvenceAlpes-Côte d'Azur, Dept. Vaucluse: Vaucluse, Morières, Plateau de Gadagne, ad terram argillaceo-sabulosum secus viam im vicinitate Querceti ilicis, 12 ii 1971, G. Clauzade \& C. Roux (Vězda, Lich. sel. exs. 987) (W 1975-261).-Portugal: Norte, Distr. Vila Real: Amieiro, terricolous on side of dust road, UTM 29TPF 3471, 7 iii 2012, f. Marques (PO) (HBG DNA no. 3731); Vale do Moinho, terricolous on side of dirt road, 7 iii 2012, F. Marques (PO) (dupl. hb. M. Schultz 17149). Centro, Distr. Coimbra: Ribeira de Relvas, 2011, 7. Marques 686 (PO) (dupl. hb. M. Schultz 17150). Algarve, Distr. Faro: NE of Albufeira, c. $7 \mathrm{~km}$ ENE of Paderne, along new road from Espargal to the south, W slope of small hill, low calcareous outcrops and a few Ceratonia siliqua trees, terricolous, $37 \cdot 214^{\circ} \mathrm{N}$, $8.1202^{\circ} \mathrm{W}, 235 \mathrm{~m}, 2009, P$. van den Boom 41781 (hb. P. van den Boom) (HBG DNA 3707).--Spain: Canary Islands: Tenerife, NW, near Buenavista del Norte, road to La Costa and Punta de la Laja, coastal scrub with Euphorbia spp., \pm exposed soil crust, $28.375^{\circ} \mathrm{N}$, $16.833^{\circ} \mathrm{W}, 50 \mathrm{~m}, 2001, M$. Schultz 17083e (hb. M. Schultz).

Heppia despreauxii (Mont.) Tuck. USA: Arizona: Cochise Co., c. $2 \mathrm{~km} \mathrm{~S}$ of Tombstone, soil over calcareous rock, 1999, M. Schultz 16097a (hb. M. Schultz).

\section{Results}

A total of six sequences were generated for this study (Table 1). The combined data set consisted of 69 taxa and 1227 unambiguously aligned sites, 663 for the mtSSU and 564 for the $M c m 7$.

Maximum likelihood analyses resulted in a single most likely tree with an ln-likelihood of $-13452 \cdot 12$. The harmonic mean lnlikelihood from the Bayesian analysis was $-13968 \cdot 6$. The tree topologies obtained by the maximum likelihood and the Bayesian approaches did not show any significant conflict (Fig. 1).

\section{Discussion}

Here we show that Epiphloea clearly belongs within the Collemataceae. This is not surprising as the Epiphloea species were classified in Collema or Leptogium when they were originally described and are very similar to other Collemataceae (sensu Wedin et al. 2009

FIG. 1. Phylogenetic position of Epiphloea within the family Collemataceae. Best tree from RAxML with bootstrap support (ML-BS) and posterior probabilities (PP) obtained in the Bayesian analysis. * Indicates a support value of $100 \%$ for ML-BS and 1 for PP. Supported clades by both analyses (ML-BS > 70, PP > 0.95) are marked with thicker black branches and with thicker grey branches when the node is only supported by one of the two analyses. 


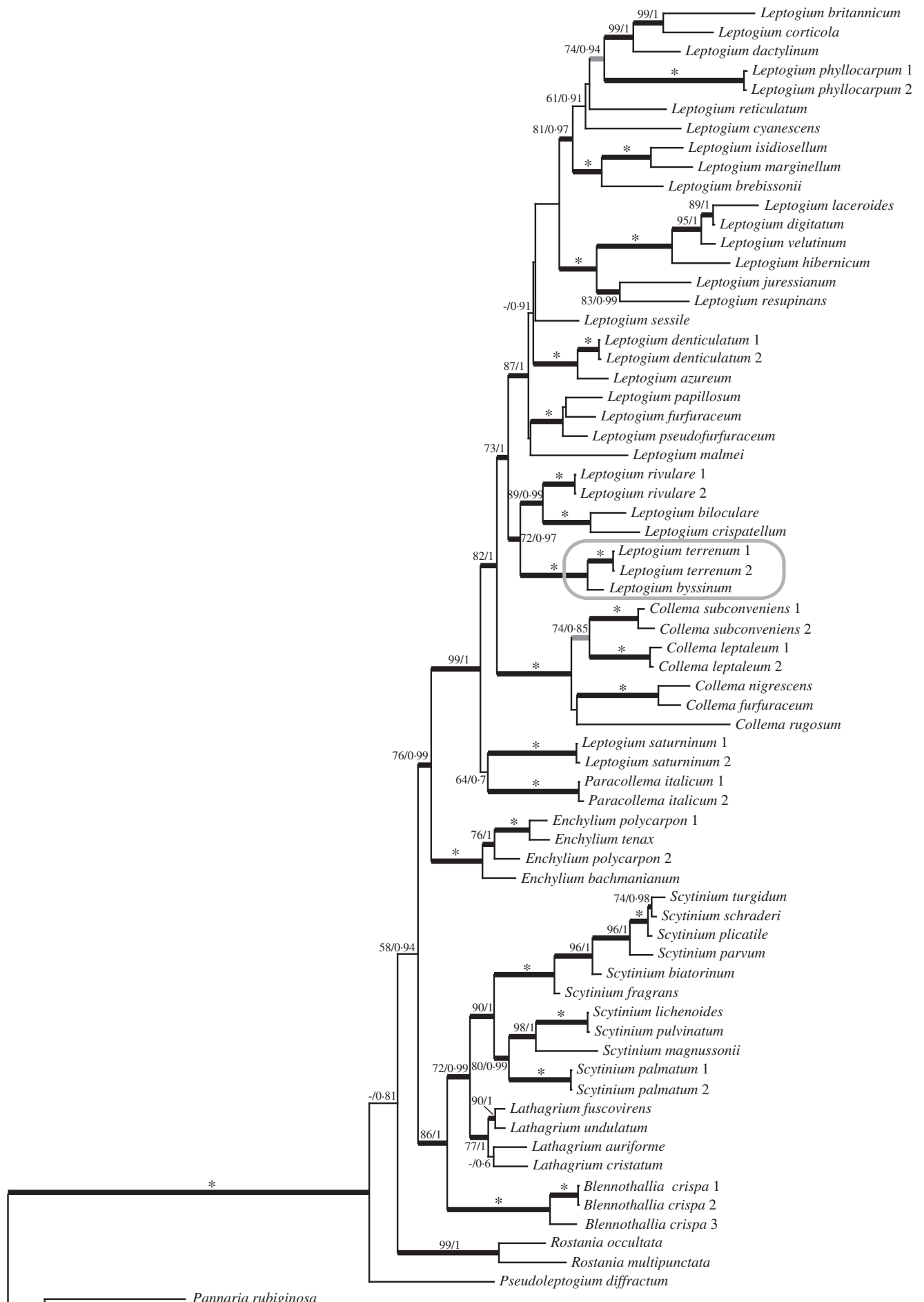

- Staurolemma omphalarioides 
and Otálora et al. 2013) in morphology (i.e. thallus structure, photobionts and ascospores; Fig. 2). Pycnidia have not been reported previously in the two Epiphloea species nor have we succeeded in seeing them. Contrary to some recent suggestions, our observations of type and other material showing that the asci in Epiphloea are Lecanoralean, with well-developed apical domes and distinct tube-like amyloid apical structures similar to other Collemataceae (Fig. 3A-C). This observation is clearly supported by the phylogenetic relationship found here. In contrast, the asci are always thin-walled in Heppiaceae (Fig. 3D), where Epiphloea used to be classified. It should be noted, however, that juvenile asci of Epiphloea are sometimes still thin-walled due to incomplete development, whereas the mature asci observed by us always had amyloid apical structures. Thus the phylogenetic placement is also supported by the ascus apex characters.

Both Epiphloea species are part of Leptogium s. str. (sensu Otálora et al. 2014), and both already have names coined in this genus. Leptogium s. str. chiefly contains corticolous species with a few exceptions such as Leptogium cyanescens (corticolous to saxicolous) or L. britannicum (growing on coastal soils). Leptogium byssinum (Hoffm.) Zwackh ex Nyl. and L. terrenum $\mathrm{Nyl}$. are two further examples of non-corticolous, soil dwelling species in the newly circumscribed genus. Furthermore, the thallus anatomy, especially in L. terrenum, adds to the variability of the genus by including species with a \pm paraplechtencymatous thallus (otherwise found in some species of Scytinium). On the other hand, both species share the typical eucortex of Leptogium: a single layer of isodiametric cells in L. byssinum (Fig. 3F) and two to three rows of isodiametric cortex cells in L. terrenum (Fig. 3E).

Leptogium byssinum and $L$. terrenum form the sister clade to Leptogium rivulare, L. crispatellum and L. biloculare, a relationship which is not so easy to explain. Difficulties in the interpretation may be due to a still incomplete taxon sampling. Leptogium rivulare has an unique ecology, growing on seasonally submerged exposed roots, soil or occasionally on rock along the margins of sluggish rivers and ponds. Leptogium crispatellum is an epiphyte known only from New Zealand. Leptogium biloculare is an epiphytic species occurring in moist, montane to subalpine regions in Australia. The three species seem to form a natural group within Leptogium s. str., but their molecular relationship with Epiphloea is not obviously corroborated by morphological and anatomical evidence. It rather seems that Leptogium byssinum and L. terrenum form a group within Leptogium s. str., with preference for disturbed and dry soil habitats combined with an otherwise somewhat unusual thallus anatomy. The general similarity in overall macro-morphology of L. byssinum and L. terrenum to species of Heppia (Lichinomycetes) is likely to be the result of parallel evolution, as these distinctly unrelated taxa have adapted to similar environmental conditions in dry soils where they form part of biological soil crusts.

\section{Nomenclatural Summary}

Leptogium (Ach.) Gray nom. cons.

prop. (Jørgensen et al. 2013)

$=$ Epiphloea Trevis., Rendiconti Reale Ist. Lombardo Sci., ser. 2 13(3): 73 (1880) syn. nov.; type: E. terrena (Nyl.) Trevis. = Amphidium Nyl., Lich. Pyren. Orient.: 72 (1891) nom. illeg., non Schimp. 1856 (bryophytes, nom. cons.); type: Amphidium terrenum (Nyl.) Nyl.

\section{Leptogium byssinum (Hoffm.) Zwackh ex Nyl.}

Actes Soc. Linn. Bordeaux 21: 270 (1857); Epiphloea byssina (Hoffm.) Henssen \& P. M. Jørg., Nordic Lich. Fl. 3: 144 (2007) syn. nov.

The following description largely follows that given by Jørgensen (1994), but according to our observations the asci are Lecanoralean with a distinct apical dome and a strongly amyloid tube-like structure (Fig. 3C).

Thallus forming a thin crust over bare soil breaking up into irregularly shaped areoles up to $3 \mathrm{~mm}$ in size, consisting of brownish granules that sometimes become increasingly dissolved into bluish, leprose granules resembling soralia (Fig. 2D), or it remains \pm crustose and corticate (Fig. 2C), attached to the substratum by pale rhizohyphae. Photobiont layer with short chains of Nostoc and 

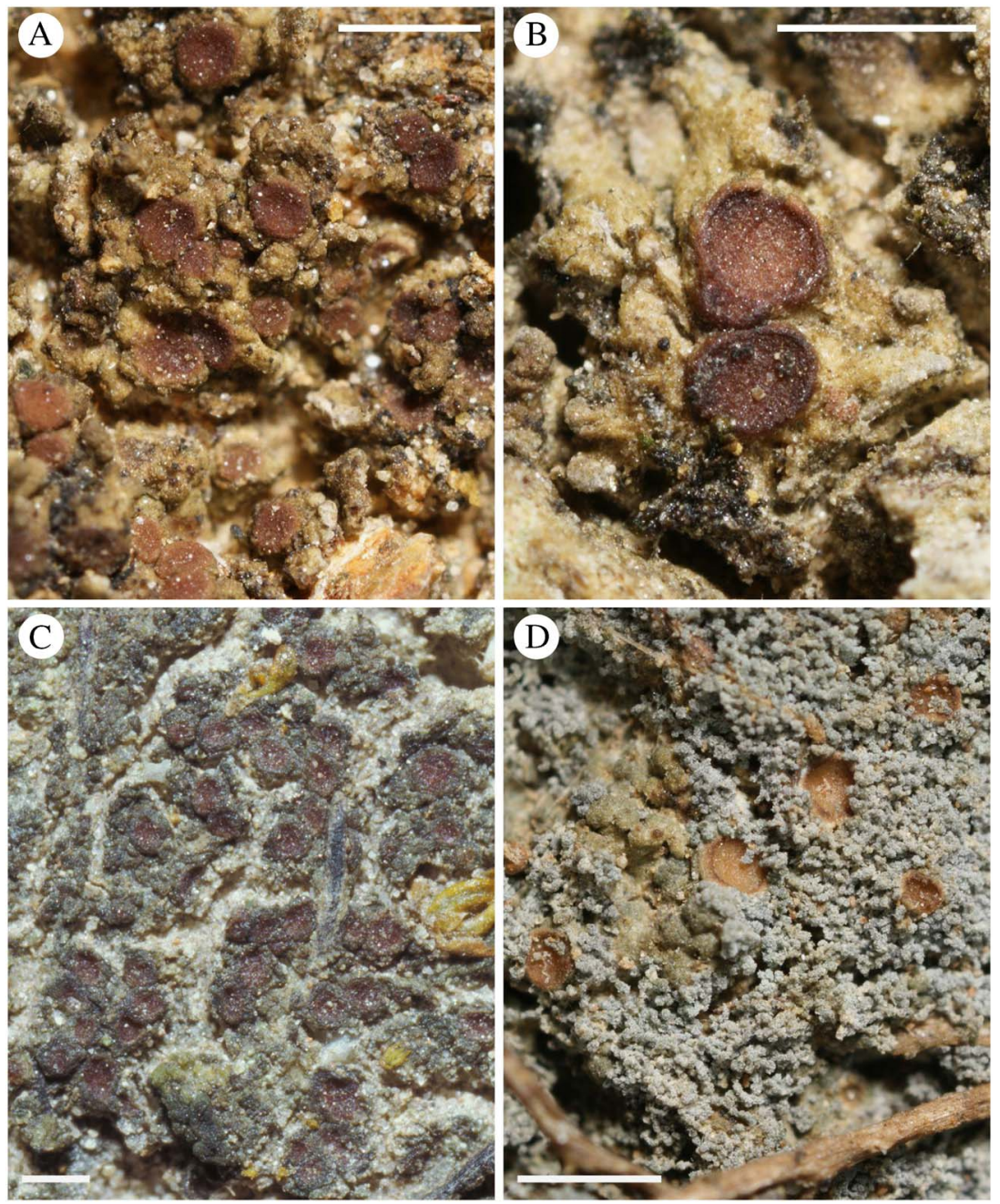

FIG. 2. A \& B, Leptogium terrenum; A, olivaceous, small-squamulose thallus, apothecia adnate, with dark red discs (Marques s. n., dupl. hb. M. Schultz 17149); B, apothecia with distinct proper exciple (Marques 686, dupl. hb. M. Schultz 17150). C \& D, Leptogium byssinum; C, dark olivaceous, crustose thallus, with semi-immersed apothecia (Flotow, Deutsch. Lich. 143A, HBG); D, thallus almost entirely dissolved into leprose, bluish (olive) granules, apothecia with brownish discs (Paukov AGP20020804-02, dupl. hb. M. Schultz). Scales $=1 \mathrm{~mm}$. In colour online

densely reticulate to paraplectenchymatous hyphae. Medulla absent, upper and lower cortex composed of a single row of isodiametric cells, $4.5-8.0 \times 4-6 \mu \mathrm{m}$ in size.

Apothecia circular, immersed to semiimmersed, rarely adnate, up to $2 \mathrm{~mm}$ diam.; disc dark reddish to brownish, initially concave, later plane, surrounded by thin thalline margin which becomes obscured in sorediate thallus parts (Fig. 2C \& D). Hymenium 100-150 $\mu \mathrm{m}$ high, $\mathrm{KOH} / \mathrm{IKI}+$ blue; proper exciple laterally thin, up to $10 \mu \mathrm{m}$ thick, composed of ellipsoid to elongated cells, $5-8 \times 3 \cdot 0-3.5 \mu \mathrm{m}$, exciple apically thickened, cells roundish, 8.0-11.5 $\times$ 7-9 $\mu \mathrm{m}$, pale reddish brown-coloured, subhymenial layer $30-40 \mu \mathrm{m}$ high; paraphyses 

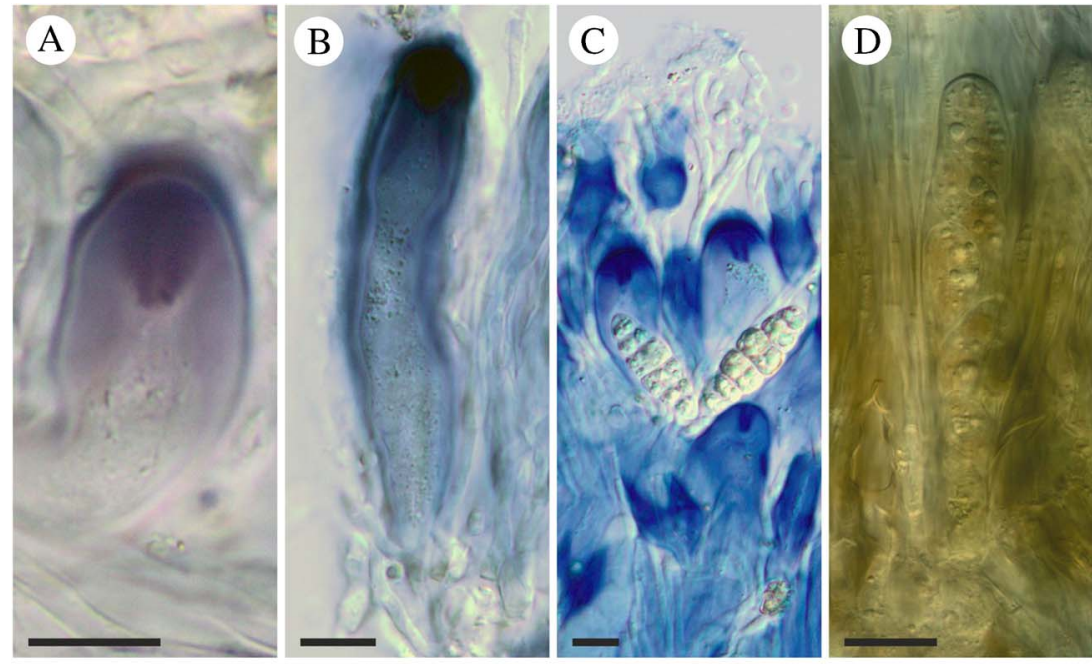

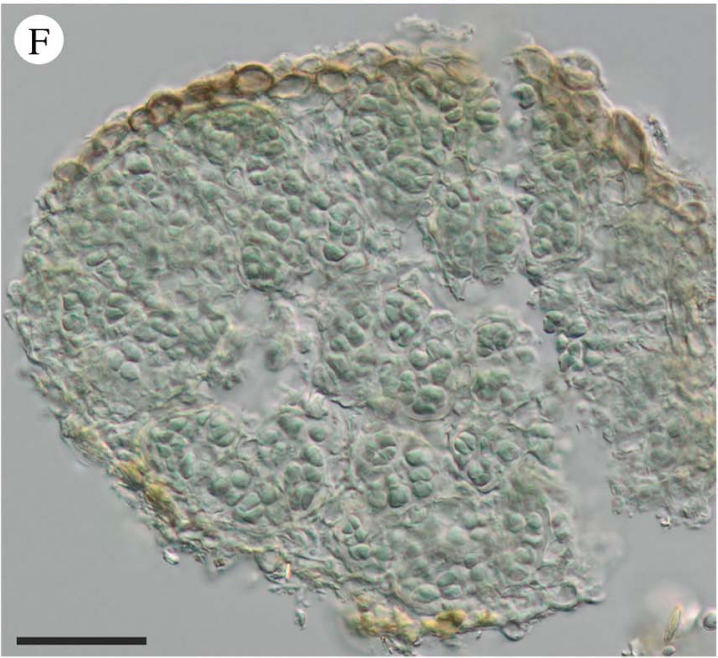

FIG. 3. A-D, asci stained with Lugol's solution after pretreatment with $\mathrm{KOH}$. A \& B, Leptogium terrenum, ascus with amyloid, tube-like apical structure (Vězda, Lich. sel. 987, W 1975-261); C, Leptogium byssinum, like A \& B, but with muriform ascospores (Körber, Lich. sel. 60, B); D, Heppia despreauxii, thin-walled, prototunicate ascus not staining with iodine, ascospores simple (Schultz 16097a, hb. Schultz); E, Leptogium terrenum, thallus cross-section showing upper cortex of isodiametric cells, photobiont layer with densely reticulate, vertically elongated cells (Marques s. n., dupl. hb. M. Schultz 17149); F, Leptogium byssinum, thallus granule surrounded by single-row cortex, photobiont layer with densely reticulate hyphae (Du Rietz, B). Scales $=10 \mu \mathrm{m}$. In colour online.

simple, straight, $1-2 \mu \mathrm{m}$ thick, terminal cells slightly enlarged. Asci narrowly clavate, $60-100 \times 10-15 \mu \mathrm{m}$ in size, 8-spored, Lecanoralean, with a distinct amyloid tube-like apical structure. Ascospores hyaline, ellipsoid, muriform, $16-28 \times 7-15 \mu \mathrm{m}$.

\section{Pycnidia unknown.}

\section{Leptogium terrenum Nyl.}

Flora 56: 195 (1873); Epiphloea terrena (Nyl.) Trevis., Rendiconti Reale Ist. Lombardo Sci., ser. 2 13(3): 73 (1880) 
syn. nov.; Amphidium terrenum (Nyl.) Nyl., Lich. Pyren. Orient.: 72 (1891) syn. nov.

Thallus resembling Heppia, with smaller irregularly shaped squamules; thallus subcrustose, (yellowish) olive, $0.4-1.2 \mathrm{~mm}$ wide, tightly to loosely adpressed (Fig. 2A), often divided into small lobules $0.4-0.8 \mathrm{~mm}$ in size, up to $150 \mu \mathrm{m}$ thick, pale below, attached to the substratum by robust, pale rhizohyphae that are indistinctly separated from the photobiont layer and composed of 1-2 rows of relatively large, isodiametric cells $10-15 \mu \mathrm{m}$ in size. Photobiont layer with short chains of Nostoc and mostly vertically arranged, reticulate hyphae composed of elongated cells (Fig. 3E). Medulla absent, lower cortex usually inconspicuous (obscured by rhizohyphae), with 1-2 rows of small, \pm isodiametric cells, $5 \cdot 0-7 \cdot 5 \mu \mathrm{m}$ in size.

Apothecia circular, at first semi-immersed, soon adnate, $0.6-0.9 \mathrm{~mm}$ diam.; disc reddish to reddish brown, widely exposed (Fig. 2B). Hymenium 100-125 $\mu \mathrm{m}$ high, $\mathrm{KOH} / \mathrm{IKI}+$ blue; proper exciple distinct, hyaline, composed of small cells of $5-10 \times 3-5 \mu \mathrm{m}$, subhymenial layer up to $100 \mu \mathrm{m}$ thick (medial sections!); paraphyses simple, straight, $1.5-2.0 \mu \mathrm{m}$ thick, terminal cells slightly enlarged. Asci narrowly clavate, 80-90 × 11-22 $\mu \mathrm{m}, 8$-spored, Lecanoralean with a distinct amyloid tube-like apical structure (Fig. 3A \& B). Ascospores hyaline, muriform, $15-26 \times 9.5-12.0 \mu \mathrm{m}$.

Pycnidia unknown.

This project was funded by two grants from the Swedish Taxonomy Initiative (Svenska Artprojektet) to MP in collaboration with MW and MS. We would like to thank Joana Marques (Kew), Martin Westberg (NRM) and Pieter van den Boom (Son) for putting fresh material at our disposal. Alexander Paukov (Yekaterinburg) is thanked for additional study material. The curators of the herbaria in B, GZU, M, STU, UPS and W are thanked for handling loan requests and we are grateful to M. G. Otálora for sharing the alignment and for her useful comments.

\section{REFERENCES}

Ekman, S., Wedin, M., Lindblom, L. \& Jørgensen, P. M. (2014) Extended phylogeny and a revised generic classification of the Pannariaceae (Peltigerales, Ascomycota). Lichenologist 46: 627-656.
Eriksson, O. E. (1999) Outline of Ascomycota - 1999. Myconet 3: 1-88.

Jørgensen, P. M. (1994) Further notes on European taxa of the lichen genus Leptogium, with emphasis on the small species. Lichenologist 26: 1-29.

Jørgensen, P. M. (2007) Heppiaceae. In Nordic Lichen Flora. Volume 3. Cyanolichens (T. Ahti, P. M. Jørgensen, H. Kristinsson, R. Moberg, U. Søchting \& G. Thor, eds): 43-45. Uppsala: Nordic Lichen Society.

Jørgensen, P. M., Otálora, M. A. G. \& Wedin, M. (2013) Proposal to conserve the name Leptogium (lichenized Ascomycota) with a conserved type. Taxon 62: 1333-1334.

Lumbsch, H. T. \& Huhndorf, S. M. (eds) (2007) Outline of Ascomycota - 2007. Myconet 13: 1-58.

Lutzoni, F., Wagner, P., Reeb, V. \& Zoller, S. (2000) Integrating ambiguously aligned regions of DNA sequences in phylogenetic analyses without violating positional homology. Systematic Biology 49: 628-651.

Maddison, W. P. \& Maddison, D. R. (2001) MacClade: Analysis of Phylogeny and Character Evolution. Version 4.01. Sunderland, Massachusetts: Sinauer Associates.

Magain, N. \& Sérusiaux, E. (2014) Do photobiont switch and cephalodia emancipation act as evolutionary drivers in the lichen symbiosis? A case study in the Pannariaceae (Peltigerales). PLoS ONE 9: e89876. doi:10.1371/journal.pone.0089876

Miądlikowska, J., Richardson, D., Magain, N., Ball, B., Anderson, F., Cameron, R., Lendemer, J., Truong, C. \& Lutzoni, F. (2014) Phylogenetic placement, species delimitation, and cyanobiont identity of endangered aquatic Peltigera species (lichenforming Ascomycota, Lecanoromycetes). American fournal of Botany 101: 1141-1156.

Miller, M. A., Pfeiffer, W. \& Schwartz, T. (2010) Creating the CIPRES Science Gateway for inference of large phylogenetic trees. In Proceedings of the Gateway Computing Environments Workshop (GCE), 14 November 2010, New Orleans, Louisiana, pp. 1-8.

Otálora, M. A. G. \& Wedin, M. (2013) Collema fasciculare belongs in Arctomiaceae. Lichenologist 45: 295-304.

Otálora, M. A. G., Aragón, G., Martínez, I. \& Wedin, M. (2013) Cardinal characters on a slippery slope - a re-evaluation of phylogeny, character evolution, and evolutionary rates in the jelly lichens (Collemataceae s. str). Molecular Phylogenetics and Evolution 68: 185-198.

Otálora, M. A. G., Jørgensen, P. M. \& Wedin, M. (2014) A revised generic classification of the jelly lichens. Collemataceae. Fungal Diversity 64: 275-293.

Posada, D. (2008) JModelTest: phylogenetic model averaging. Molecular Biology and Evolution 25: 1253-1256.

Prieto, M., Baloch, E., Tehler, A. \& Wedin, M. (2013) Mazaedium evolution in the Ascomycota (Fungi) and the classification of mazaediate groups of unclear relationship. Cladistics 29: 296-308. 
Rambaut, A. \& Drummond, A. J. (2007) Tracer v.1.4. http://beast.bio.ed.ac.uk/Tracer.

Rodríguez, F., Oliver, J. F., Marin, A. \& Medina, J. R. (1990) The general stochastic model of nucleotide substitution. Fournal of Theoretical Biology 142: 485-501.

Ronquist, F., Teslenko, M., van der Mark, P., Ayres, D., Darling, A., Höhna, S., Larget, B., Liu, L., Suchard, M. A. \& Huelsenbeck, J. P. (2012) MrBayes 3.2: efficient Bayesian phylogenetic inference and model choice across a large model space. Systematic Biology 61: 539-542.

Schmitt, I., Crespo, A., Divakar, P. K., Frankhauser, J. D., Herman-Sackett, E., Kalb, K., Nelsen, M. P., Rivas Plata, E., Shimp, A. D., Widhelm, T. et al. (2009) New primers for promising single-copy genes in fungal phylogenetics and systematics. Persoonia 23: 35-40.

Schoch, C. L., Sung, G.-H., López-Giráldez, F., Townsend, J. P., Miądlikowska, J., Hofstetter, V., Robbertse, B., Matheny, P. B., Kauff, F., Wang, Z. et al. (2009) The Ascomycota tree of life: a phylum wide phylogeny clarifies the origin and evolution of fundamental reproductive and ecological traits. Systematic Biology 58: 224-239.
Spribille, T. \& Muggia, L. (2013) Expanded taxon sampling disentangles evolutionary relationships and reveals a new family in Peltigerales (Lecanoromycetidae, Ascomycota). Fungal Diversity 58: 171-184.

Stamatakis, A. (2014) RAxML Version 8: a tool for phylogenetic analysis and post-analysis of large phylogenies. Bioinformatics 30: 1312-1313.

Wedin, M., Wiklund, E., Jørgensen, P. M. \& Ekman, S. (2009) Slippery when wet: phylogeny and character evolution in the gelatinous cyanobacterial lichens (Peltigerales, Ascomycetes). Molecular Phylogenetics and Evolution 53: 862-871.

Wedin, M., Jørgensen, P. M. \& Ekman, S. (2011) Vahliellaceae, a new family of cyanobacterial lichens (Peltigerales, Ascomycetes). Lichenologist 43: 67-72.

Zahlbruckner, A. (1919) Vorarbeiten zu einer Flechtenflora Dalmatiens. Oesterreichische Botanische Zeitschrift 68: 60-77, 148-165, 237-253, 297-326.

Zahlbruckner, A. (1924-1925) Catalogus Lichenum Universalis. Band III. Leipzig: Borntraeger.

Zoller, S., Scheidegger, C. \& Sperisen, C. (1999) PCR primers for the amplification of mitochondrial small subunit ribosomal DNA of lichen-forming ascomycetes. Lichenologist 31: 511-516. 